\title{
Freshwater gomphonemoid diatom phylogeny: preliminary results
}

\author{
J.P. Kociolek ${ }^{1}$ \& E.F. Stoermer ${ }^{2}$ \\ ${ }^{1}$ Diatom Collection, Department of Invertebrate Zoology \& Geology, California Academy of Sciences, \\ Golden Gate Park, San Francisco, CA 94118, USA; ${ }^{2}$ Center for Great Lakes and Aquatic Sciences, The \\ University of Michigan, 2200 Bonisteel Boulvard, Ann Arbor, MI 48109, USA
}

Key words: cladistics, Gomphoneis, Gomphonema, Gomphopleura, phylogeny

\begin{abstract}
A cladistic analysis of eleven freshwater gomphonemoid diatom taxa yielded three equally most parsimonious cladograms. The three cladograms suggest Gomphoneis Cleve is non-monophyletic as originally and recently circumscribed. Gomphoneis elegans and G. transsilvanica (Pant.) Krammer are more closely related to Gomphopleura Reichelt ex Tempère than to other members of the genus. Gomphoneis geitleri Kociolek \& Stoermer appears to represent a monotypic lineage. Among the taxa with differentiated apical pore fields Gomphonema kaznakowi Mereschkowsky appears to be primitively astigmate.

The three cladograms vary with regard to systematic affinities among the Gomphoneis herculeana (Ehrenberg) Cleve group, Miocene gomphonemoid species from Idaho (USA), gomphonemoid taxa from East Africa and Gomphonema sensu stricto. Despite variability in number of puncta rows per stria and presence of an axial plate in the Miocene species from North America, inclusion of these taxa in the analysis provided better resolution of relationships than if they were excluded.
\end{abstract}

\section{Introduction}

Recent ultrastructural observations on members of the freshwater gomphonemoid diatom clade (sensu Kociolek \& Stoermer, 1988a), i.e. Gomphonema C.A. Ag., Gomphoneis Cleve, Gomphocymbella $\mathrm{O}$. Müller and Gomphopleura Reichelt ex Tempère, have piqued our interest as to their genealogical relationships. Our initial analysis of relationships in Gomphoneis (Kociolek \& Stoermer, 1989) assumed monophyly for the genus and showed it to be comprised of two distinct monophyletic lineages (the "Elegans" and "Herculeana" subgroups) and to have a sister taxon relationship with at least some species of Gomphonema. In an initial examination of fresh- water cymbelloid and gomphonemoid diatom phylogeny (Kociolek \& Stoermer, 1988a), monophyly of Gomphoneis was supported, but its interrelationships with Gomphonema and Gomphocymbella were unresolved and no features found which diagnose Gomphonema. We recently suggested (Kociolek \& Stoermer, Accepted) that Gomphocymbella sensu lato was non-monophyletic; $G$. ancyli is more closely allied to the cymbelloid lineage of diatoms (which includes Cymbella C.A. Ag., Encyonema Kütz., Reimeria Kociolek \& Stoermer and Didymosphenia M. Schm.; see Kociolek \& Stoermer, 1988a) (a view suggested by Krammer \& Lange-Bertalot, 1986) and the East African species of Gomphocymbella share a more recent common ancestor with a 
clade of Gomphonema species from the same biogeographic area.

Electron microscopic observations of valve ultrastructure of Gomphonema species suggest the genus may be more finely dissected than previously attempted (e.g. Dawson, 1973). There are species with external flaps or occlusions in the puncta (Gomphonema sensu stricto, $G$. ventricosum Greg. G. clevei Fricke, Dawson, 1973; Kociolek \& Stoermer, 1991a), species with puncta occlusions internal (e.g. G. intricatum Kütz., G. semiapertoides Kociolek \& Stoermer, G. epiphanes Kociolek \& Stoermer, Kociolek \& Stoermer, 1990; Reichardt \& Lange-Bertalot, 1991) and groups lacking occlusions altogether (e.g. East African species such as G. africanum West, G. aequatoriale Hustedt, Kociolek \& Stoermer, 1991b). While most species have a slit-like internal stigmal opening, some Gomphonema species have rounded internal stigmal openings (e.g. G. clevei, Kociolek \& Stoermer, 1991a) and others lack stigmata ( $G$. kaznakowi Mereschkowsky, Kociolek, Accepted). Gomphonema grovei and its allies, which have single, elongated foraminae, lack apical pore fields, septa and pseudosepta, and have anchor-shaped internal proximal raphe ends (Krammer \& Lange-Bertalot, 1986; Kociolek et al., 1988; Kociolek \& Stoermer, 1990), appear very different morphologically from any other members of freshwater gomphonemoid diatoms. Its placement in Gomphonema and the entire clade is doubtful (Krammer \& Lange-Bertalot 1991).

Character combinations of recent and fossil taxa recently investigated make distinctions between Gomphonema and Gomphoneis less clear than previously suggested. Description of Gomphoneis geitleri Kociolek \& Stoermer, from the Laurentian Great Lakes, for example, showed this taxon to possess a unique suite of features, some of which are shared with both the Elegans and Herculeana groups of Gomphoneis (undifferentiated apical pore fields as in the Elegans group but a single isolated puncta as in the Herculeana group) as well as Gomphonema species (lack of internal siliceous laminae; Kociolek \& Stoermer, 1991a). Miocene species from the Hot Springs
Limestone of Idaho (USA) have combinations of characters that include number of puncta per stria, and presence of an axial plate and relate them to the Herculeana group of Gomphoneis and Gomphonema (Kociolek \& Stoermer, 1990).

Despite the morphological variations exhibited in these taxa, they are no doubt closely related ( $G$. grovei and allies excepted), part of a distinct lineage which share cytoplasmic and valve features (Kociolek \& Stoermer, 1988a). The purpose of this report is to integrate recent observations on valve ultrastructure into a phylogenetic hypothesis regarding the interrelationships of these closely related taxa. Such an hypothesis may help refine/ clarify previous findings and shed new light on questions of evolutionary descent of this widely distributed, ecologically-important group of diatoms.

\section{Materials and methods}

\section{Cladistic analysis}

Cladistic analysis attempts to construct hypotheses of interrelationships by using shared, derived features (called synapomorphies). Detailed descriptions of cladistic analysis can be found in Wiley (1981), Eldredge \& Cracraft (1980) and Wiley et al. (1991). Williams (1985, 1990), Williams \& Round (1988), Kociolek \& Stoermer (1986a, 1988a, 1989) and Theriot et al. (1987) have used cladistics methods to understand diatom interrelationships, and Kociolek et al. (1989) provide an explanation of cladistic methods with diatom examples.

\section{Terminal taxa}

Eleven terminal taxa considered in this work are listed in Table 1. Gomphonema has been split into groups based on presence of puncta occlusions (a single terminal taxon comprised of the subgroups Gomphonema sensu stricto, $G$. ventricosum, $G$. intricatum and G. clevei), and those lacking occlusions. The latter group is subdivided into four 
Table 1. Terminal taxa used in cladistic analysis and literature references used to summarize their morphologies.

\begin{tabular}{ll}
\hline Taxa & References \\
\hline Brebissonia (outgroup) & Mahoney \& Reimer, 1986 \\
& \\
Gomphoneis & Kociolek \& Stoermer, 1988b, d \\
Elegans group & Kociolek \& Stoermer, 1986b, 1988c \\
Herculeana group & Kociolek \& Stoermer, 1991a \\
G. geitleri & Kociolek \& Stoermer, 1990 \\
G. magna & Krammer, 1982 \\
G. transsilvanica & \\
Gomphonema & \\
Sensu Stricto + Intricatum + & Dawson, 1973; Kociolek \& \\
Ventricosum + Clevei & Stoermer, 199la, b; Reichardt \& \\
East African Gomphonema + & Lange-Bertalot 1991 \\
$\quad$ Gomphocymbella species & Kociolek \& Stoermer, 1991b, \\
G. blandiculum & Kociolek \& Stoermer, 1990 \\
G. kaznakowi & Kociolek, Accepted \\
G. medio-inflatum & Kociolek \& Stoermer, 1990 \\
Gomphopleura & Mahoney, 1989 \\
\hline
\end{tabular}

groups, including certain East African species of Gomphonema (e.g. G. africanum, G. aequatoriale, G. kilhamii Kociolek \& Stoermer, G. paddockii Kociolek \& Stoermer) and East African Gomphocymbella species, G. blandiculum Kociolek \& Stoermer, G. medio-inflatum Kociolek \& Stoermer (both fossil species with interesting combinations of characters) and G. kaznakowi. Gomphoneis is split into the Herculeana group, from which $G$. magna has been segregated because of its unique suite of features, and the Elegans group has been subdivided into Elegans sensu stricto, $G$. transsilvanica (Pant.) Krammer and G. geitleri. Also included in the analysis is Gomphopleura, a genus with many similarities with other members of this lineage (Mahoney, 1989). The outgroup used for this analysis is Brebissonia; this brackishwater taxon was suggested by Kociolek \& Stoermer (1988a) to be the sister taxon to the freshwater gomphonemoid diatoms. Ultrastructural features of the outgroup and terminal taxa were taken from published literature. Literature citations are provided next to each terminal taxon in Table 1.
Characters and character analysis

Thirteen characters, twelve of which are binary and one is multi-state were used to construct the cladograms. The taxa and coding of their features relative to the thirteen characters are presented in Table 2. Characters and character states are described below.

1. Asymmetry: Asymmetry here is meant to include an apical pore field at one pole only and being cuneate in girdle view, features found in all terminal taxa, but absent in the outgroup, and considered to help define the entire lineage. States: Absent (0), Present (1).

2. Marginal laminae: A sheet of silica covering the interior of the mantle, sometimes extending beneath the valve face at the margin (e.g. Gomphoneis elegans; cf. Kociolek \& Stoermer, 1988b). States: Absent (0), Present (1).

3. Puncta rows: Number of rows of puncta comprising each stria. States: One $(0)$, Two (1), > Two (2). More than two rows of puncta

Table 2. Listing of terminal taxa, characters and coding of character states used in cladistic analysis. Character numbers refer to those presented in Materials and Methods.

\begin{tabular}{lr}
\hline Taxa & \multicolumn{1}{c}{$\begin{array}{c}\text { Characters } \\
1234567891111 \\
0123\end{array}$} \\
\hline Brebissonia (outgroup) & 0010000000000 \\
Gomphoneis & \\
Elegans group & 1111100010000 \\
Herculeana group & 1111110000111 \\
G. geitleri & 1011100001000 \\
G. magna & 1111100000111 \\
G. transsilvanica & 1121100000000 \\
& \\
Gomphonema & \\
Sensu Stricto + Intricatum + & 1001101000111 \\
$\quad$ Ventricosum + Clevei & \\
East African Gomphonema + & 1001100000111 \\
$\quad$ Gomphocymbella species & \\
G. blandiculum & 1011100000111 \\
G. kaznakowi & 1001100000010 \\
G. medio-inflatum & 1001110000111 \\
Gomphopleura & 1111110100000 \\
\hline &
\end{tabular}


per stria are found in Gomphoneis transsilvanica (Krammer, 1982). This multi-state character was considered unordered.

4. Septa: Laminae of silica projecting in to the interior of the cell from the girdle band. Present at both poles and in all terminal taxa. States: Absent (0), Present (1).

5. Pseudosepta: Laminae of silica projecting in to the interior of the cell from the margin of the valve. Use of this term is different than the recommended terminology of Anonymous (1975). Present at both poles and in all terminal taxa. With presence of asymmetry and septa, this feature is used to help diagnose the lineage. States: Absent (0), Present (1).

6. Axial plate: Internal lamina of silica running along the axial area on the interior of the valve; may run the entire length or only a portion of the valve. States: Absent (0), Present (1).

7. Puncta occlusions: Siliceous flaps or protrusions occuring in the openings of the puncta (cf. Mann, 1981). Found only in the Gomphonema subgroups of Intricatum, Sensu Stricto, Clevei and Ventricosum. States: Absent (0), Present (1).

8. Reduced raphe: Raphe not extending to the central portion of the valve. Found only in Gomphopleura. States: Absent (0), Present (1).

9. Stigmoids: Openings in the central area (externally) and about the central nodule (internally), not extending onto the central nodule. May be obstructed or free of protrusions. States: Absent (0), Present (1).

10. Stigma with internal covering: Openings in the central area (externally) and on the central nodule (internally); internal opening has a perforated cover. Observed in Gomphoneis geitleri only. States: Absent (0), Present (1).

11. Stigma with opening slit-like: Openings in the central area (externally) and on the central nodule (internally); internal expression of stigmal opening is narrow and slit-like. Not considered homologous with covered open- ing described in (10) above. States: Absent (0), Present (1).

12. Apical pore field differentiated from puncta. Porelli comprising apical pore fields are physically removed (usually separated by an unornamented strip of silica) and structurally differentiated from the puncta. States: $\mathrm{Ab}$ sent (0), Present (1).

13. External distal raphe ends deflected: Raphe ends bend or curve to a significant degree at the terminus on the valve exterior. States: Absent (0), Present (1).

\section{Analysis}

Characters were treated as unordered and analyzed with MacPaup (version 3.0S; Swofford, 1991), using the Branch and Bound method for finding the most parsimonious trees. A strict consensus tree was computed using all equally most parsimonious trees.

\section{Results}

Three equally most parsimonious cladograms were calculated by MacPaup and are presented in Figure 1. The trees require 18 steps and have a Consistency Index (CI) of $0.778(\mathrm{CI}=0.636 \mathrm{ex}-$ cluding uninformative characters, i.e. autapomorphies).

The three trees have similar topologies with regard to early branches in the lineage. The entire lineage is diagnosed by the synapomorphies of asymmetry, presence of septa and pseudosepta. There is an unresolved trichotomy at the base of the clade. One line of the trichotomy contains Gomphopleura, the Elegans subgroup of Gomphoneis and $G$. transsilvanica and is diagnosed by the synapomorphy of presence of marginal laminae. The features of significantly shortened raphe branches and presence of a short axial plate are autapomorphic for Gomphopleura, while presence of stigmoids and multipunctate striae are autapomorphic for the Gomphoneis elegans subgroup and $G$. transsilvanica, respectively. The $G$. elegans 
subgroup is polythetic, since some members do not have the feature that diagnoses the group, i.e. G. olivacea (Hornemann) Dawson ex Ross \& Sims (Kociolek \& Stoermer 1989).

The second branch of the initial trichotomy is comprised solely of G. geitleri, which has the autapomophic feature of a perforated covering over the internal stigmal opening. The third line is diagnosed by presence of differentiated apical pore fields. Within this third clade, the first branch, with the autapomorphic feature of singlypunctate striae, is comprised of Gomphonema kaznakowi only. Slit-like stigmata and deflected external distal raphe ends are synapomorphies for the rest of the clade, which includes the East African line of Gomphonema and Gomphocymbella taxa, Gomphonema, Gomphoneis magna and the Herculeana group of Gomphoneis, Gomphonema blandiculum and G. medio-inflatum. Their interrelationships among one another vary based on
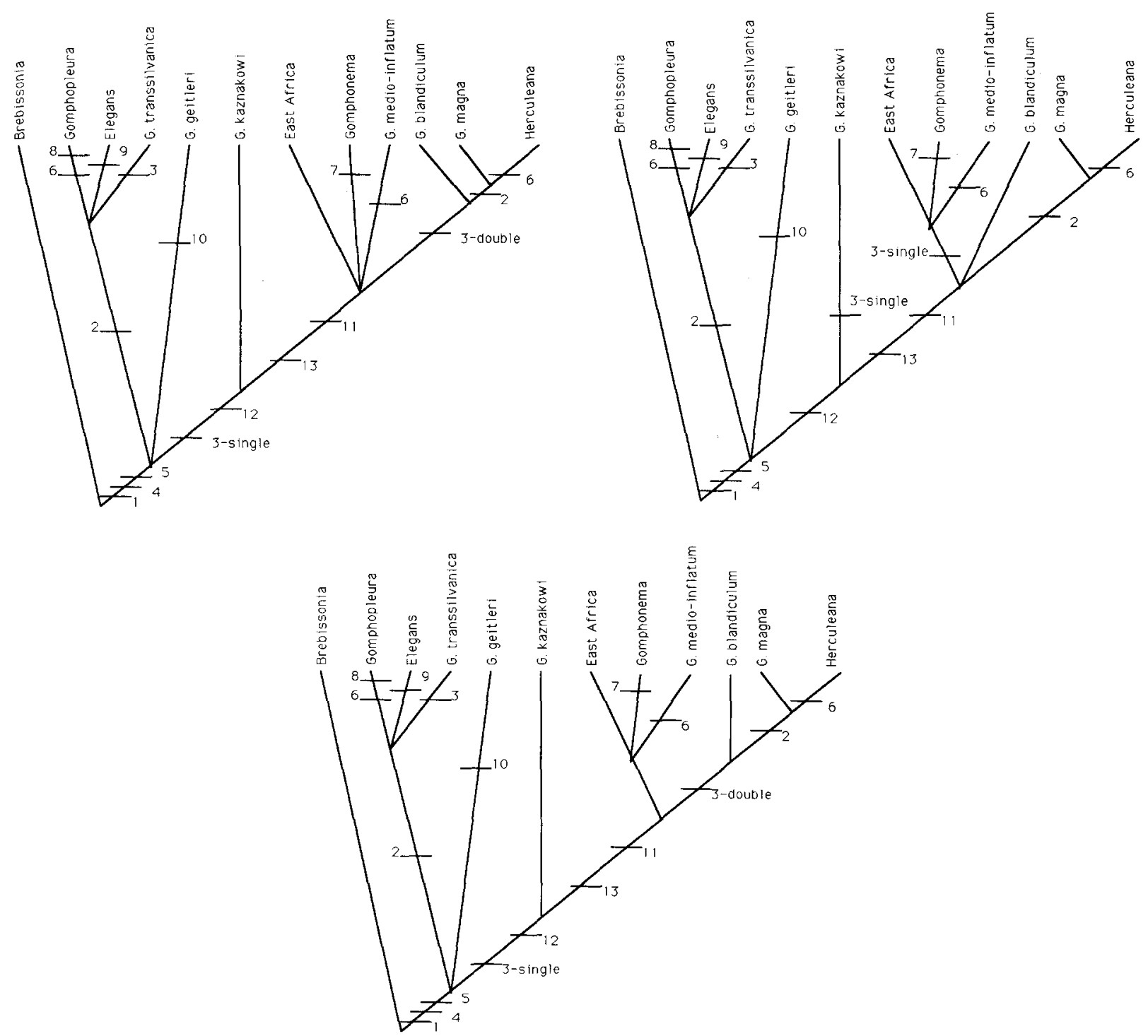

Figs $1 a-c$. Three equally most parsimonious cladograms of 11 freshwater gomphonemoid diatom taxa based on 13 features. See text for description of characters. 
number of puncta rows comprising the striae and presence of an axial plate (Figs 1a-c). A strict consensus tree of the the three equally most parsimonious cladograms (Fig. 2) indicates the relationships of these groups are unresolved.

\section{Discussion}

The cladograms clearly indicate that Gomphoneis, as defined by Cleve (1894), Dawson (1973), Krammer (1982), and Kociolek \& Stoermer (1988a), is not monophyletic. The two subgroups established for the genus by Kociolek \& Stoermer (1988a), the Elegans and Herculeana subgroups, each share a more recent common ancestor with other taxa (Gomphopleura and Gomphonema, respectively) than they do with each other. This is not surprising considering the range of morphological diversity contained in Gomphoneis sensu lato. Features used to diagnose Gomphoneis by Kociolek \& Stoermer (1989), namely doublypunctate striae and marginal laminae, are considered in this hypothesis to be symplesiomorphies (doubly-punctate striae are found in the outgroup) or converged upon by two lineages (the Elegans + Gomphopleura + Gomphoneis transsilvanica

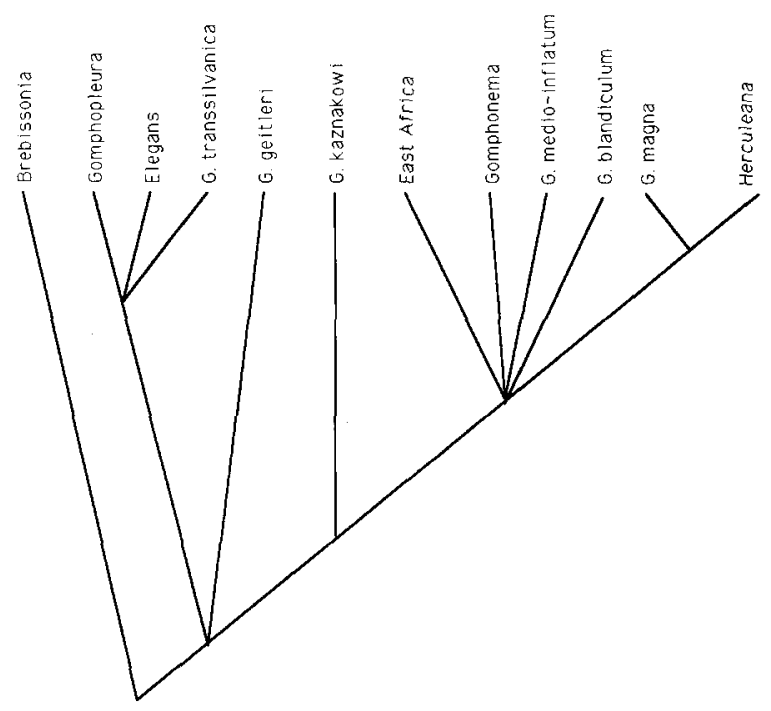

Fig. 2. Strict consensus tree topology of three cladograms shown in figure 1 . line and $G$. herculeana subgroup + G. magna). Relationships within the Elegans and Herculeana subgroups have not necessarily changed from those described in Kociolek \& Stoermer (1989).

One taxon thought to be part of the Elegans subgroup is G. geitleri (Kociolek \& Stoermer, 1991a). The phylogenetic analysis presented here suggests the relationship of $G$. geitleri is unresolved between the line containing $G$. elegans and its allies and the gomphonemoid diatoms with differentiated apical pore fields. It appears to represent an evolutionary line that, as far as we know, has not been successful in terms of species numbers or distribution (G. geitleri is known only from North America). It may be that G. geitleri demonstrates the asymmetry of evolutionary lineages, as suggested by Darwin (1859) generally and by Round (1981) for diatoms specifically.

It may be possible to partially resolve relationships of the four groups within Gomphonema, since three, $G$. ventricosum, $G$. sensu stricto and $G$. clevei, possess occlusions on the exterior of the valve (Dawson, 1973; Kociolek \& Stoermer, 1991b), while members of the G. intricatum group have occlusions on the interior of the puncta (Kociolek \& Stoermer, 1990, 1991a; Reichardt \& Lange-Bertalot, 1991). If external puncta occlusions are the synapomorphic condition, the three groups that have this feature would be differentiated from the G. intricatum line (Fig. 3a). If internal occlusions represent the derived state, then resolution of the four groups is not possible with this state; the feature of internal occlusions would be autapomorphic for the $G$. intricatum line (Fig. 3b).

Initial consideration of the Miocene Gomphonema and Gomphoneis species of the Herculeana clade from the Hot Springs Limestone (Kociolek \& Stoermer, 1990) suggested boundaries between these two major groups are fuzzy. Gomphoneis magna, for example, was referred to the genus on the presence of marginal laminae and partially doubly-punctate striae (single rows on the valve face, double rows on the margin and mantle), as well as a slit-like internal stigmal opening and differentiated apical pore fields. Gomphonema blandiculum has doubly-punctate striae and lacks 

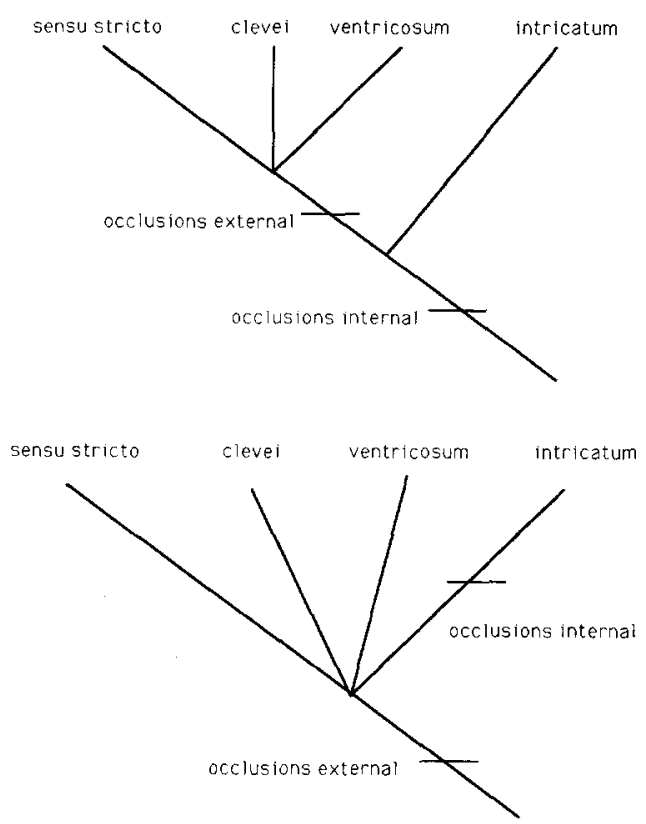

Figs 3a, $b$. Possible resolutions of Gomphonema subgroup interrelationships based on position of puncta occlusions.

occlusions in the puncta, but otherwise resembles other members of Gomphonema. Gomphonema medio-inflatum and its allies have singly-punctate striae, lack marginal laminae but possess small axial plate-like structures around the central area. Inclusion of these extinct species in the phylogenetic analysis actually provides greater resolution of relationships than if they were not included since the resulting consensus cladogram without these taxa is an unresolved polytomy of all terminal taxa. This apparent paradox of including these more "variable" taxa and yielding better phylogenetic resolution is yet another example of the importance of fossil taxa in phylogenetic analyses (cf. Gauthier et al., 1988; Donoghue et al., 1989).

The differing combinations of characters seen in these apparently early members of this extremely successful line of gomphonemoid diatoms (in terms of species and distribution) suggests that the characters have not yet become firmly established in the lineage. This condition is reminiscent of the Burgess Shale fauna (Gould, 1991), where strange combinations of characters occur in the early invertebrates. Riedl (1978) has suggested that early in the evolution of a group, certain features may not be fully integrated into functional systems and thus may be highly variable in their distribution within and across taxa. These features are said to have low evolutionary "burden". As the lineage develops, integration of features, functionally or ontogenetically, occurs and burden of the feature(s) increases, to the point where it is less variable in the group. Riedl's concept of burden might be useful in examining character distributions in the early gomphonemoid diatoms, and more generally relative to how characters may be more or less prone to vary in the history of a group. We need, however, a better understanding of the origin and early evolution of the lineage before Riedl's burden concept might be applied to the group.

Uncertainty about the phylogenetic relationships of the stigma-bearing freshwater gomphonemoid diatoms, and their potential for testing hypotheses about character variability and distributions over time and space, suggest this successful group of diatoms warrants considerably more attention with regard to its taxonomy, ultrastructure and biogeography.

\section{References}

Anonymous, 1975. Proposals for a standardization of diatom terminology and diagnoses. Nova Hedwigia Beih. 53: 323354.

Cleve, P.T., 1894. Synopsis of the naviculoid diatoms. Part 1. K. Svensk. Vetens-Akad. Handl. 26: 1-194.

Darwin, C., 1859. On the origin of species by means of natural selection, or the preservation of favored races in the struggle for life. J. Murray, London.

Dawson, P.A., 1973. Observations on some species of the diatom genus Gomphonema C.A. Agardh. Br. phycol. J. 8: 413-423.

Donoghue, M.J., J.A. Doyle, J. Gauthier, A.G. Kluge \& T. Rowe, 1989. The importance of fossils in phylogeny reconstruction. Ann. Rev. Ecol. Syst. 20: 431-460.

Eldredge, N. \& J. Cracraft, 1980. Phylogenetic patterns and the evolutionary process. Columbia Univ. Press, New York, 349 pp.

Gauthier, J., A.G. Kluge \& T. Rowe, 1988. Amniote phylogeny and the importance of fossils. Cladistics 4: 105-209.

Gould, S.J., 1991. The disparity of the Burgess Shale arthropod fauna and the limits of cladistic analysis: Why we must 
strive to quantify morphospace. Paleobiology 17: 411-423.

Kociolek, J.P., Accepted. Valve ultrastructure and systematic position of Gomphonema kaznakowi Mereschkowsky. Diatom Res.

Kociolek, J.P. \& E.F. Stoermer, 1986a. Phylogenetic relationships and classification of monoraphid diatoms based on phenetic and cladistic methodologies. Phycologia 25: 297303.

Kociolek, J.P. \& E.F. Stoermer, 1986b. Observations on North American Gomphoneis (Bacillariophyceae). II. Descriptions and ultrastructure of two new species. Trans. Am. Microsc. Soc. 105: 141-151.

Kociolek, J.P. \& E.F. Stoermer, 1988a. A preliminary investigation of the phylogenetic relationships of the freshwater, apical pore field-bearing cymbelloid and gomphonemoid diatoms (Bacillariophyceae). J. Phycol. 24: 377-385.

Kociolek, J.P. \& E.F. Stoermer, 1988b. Observations on North American Gomphoneis (Bacillariophyceae). IV. Valve ultrastructure and systematic position of Gomphoneis elegans. Trans. Am. Microsc. Soc. 107: 386-396.

Kociolek, J.P. \& E.F. Stoermer, 1988c. Taxonomy, ultrastructure, and distribution of Gomphoneis herculeana, $G$. eriense and closely related species. Proc. Acad. nat. Sci. Philad. 140: 24-97.

Kociolek, J.P. \& E.F. Stoermer, 1988d. Taxonomic and systematic position of the Gomphoneis quadripunctata-species complex. Diatom Res. 3: 95-108.

Kociolek, J.P. \& E.F. Stoermer, 1989. Phylogenetic relationships and evolutionary history of the diatom genus Gomphoneis, Phycologia 28: 438-454.

Kociolek, J.P. \& E.F. Stoermer, 1990. Diatoms from the Upper Miocene Hot Springs Limestone, Snake River Plain, Idaho (U.S.A.). Micropaleont. 36: 331-352.

Kociolek, J.P. \& E.F. Stoermer, 1991a. New and interesting Gomphonema species from East Africa. Proc. Cal. Acad. Sci. 47: 275-288.

Kociolek, J.P. \& E.F. Stoermer, 1991b. Taxonomy and ultrastructure of some Gomphonema Ehrenberg and Gomphoneis Cleve taxa from the upper Laurentian Great Lakes. Can. J. Bot. 69: 1557-1576.

Kociolek, J.P. \& E.F. Stoermer, in press. The diatom genus Gomphocymbella $\mathrm{O}$. Müller: Taxonomy, ultrastructure and phylogenetic relationships. In P.A. Sims (ed.), Robert Ross Festschrift. O. Koeltz, Koenigstein.

Kociolek, J.P., E.C. Theriot \& D.M. Williams, 1989. Inferring diatom phylogeny: a cladistic perspective. Diatom Res. 4: 289-300.

Kociolek, J.P., J.-R. Yang \& E.F. Stoermer, 1988. Taxonomy, ultrastructure and systematic position of the Gomphonema grovei M. Schm.-species complex (Bacillariophyceae). Nova Hedwigia 47: 145-158.

Krammer, K. 1982. Observations on the alveoli and areolae of some Naviculaceae. Nova Hedwigia, Beih. 73: 55-80.
Krammer, K. \& H. Lange-Bertalot, 1986. Bacillariophyceae. Süsswasserflora von Mitteleuropa, 2 (1). G. Fisher, Stuttgart, $876 \mathrm{pp}$.

Krammer, K. \& H. Lange-Bertalot, 1991. Bacillariophyceae. Süsswasserflora von Mitteleuropa, 2 (4). G. Fisher, Stuttgart, $437 \mathrm{pp}$.

Mahoney, R.K., 1989. Observations on the diatom Gomphopleura nobilis Reichelt ex Tempère (Bacillariophyceae). Proc. Acad. nat. Sci. Philad. 141: 251-261.

Mahoney, R.K. \& C.W. Reimer, 1986. Studies on the genus Brebissonia Grun. (Bacillariophyta). I. Introduction and observations on $B$. lanceolata comb. nov. In M. Ricard (ed.), Proceedings of the 8th Symposium on Living and Fossil Diatoms. O. Koeltz, Koenigstein: 183-190.

Mann, D.G., 1981. Sieves and flaps: siliceous minutiae in the pores of raphid diatoms. In R. Ross (ed.), Proceedings of the 6th Symposium on Recent and Fossil Diatoms. O. Koeltz, Koenigstein: 279-300.

Reichardt, E. \& H. Lange-Bertalot, 1991. Taxonomische revision des Artenkomplexes um Gomphonema angustatum- $G$. dichotomum-G. intricatum-G. vibrio und ahnliche Taxa (Bacillariophyceae). Nova Hedw. 53: 519-544.

Riedl, R., 1978. Order in living organisms. J. Wiley \& Sons, New York, 313 pp.

Round, F.E., 1981. Morphology and phyletic relationships of the silicified algae and the archetypal diatom-monophyly or polyphyly. In T.L. Simpson \& B.E. Volcani (eds.), Silicon and siliceous structures in biological systems. SpringerVerlag, New York: 97-128.

Swofford, D.L., 1991. User's Manual for PAUP 3.0. Illinois Natural History Survey, Champaign, $178 \mathrm{pp}$.

Theriot, E.C., E.F. Stoermer \& H. Håkansson, 1987. Taxonomic interpretation of the rimoportula of freshwater genera in the centric diatom family Thalassiosiraceae. Diatom Res. 2: 251-265.

Wiley, E.O., 1981. The theory and practice of phylogenetic systematics. J. Wiley \& Sons, New York, 439 pp.

Wiley, E.O., D. Siegel-Causey, D.R. Brooks \& V.A. Funk, 1991. The Compleat Cladist. A primer of phylogenetic procedures. University of Kansas Museum of Natural History Special Publication 19, Lawrence, $158 \mathrm{pp}$.

Williams, D.M., 1985. Morphology, taxonomy and interrelationships of the ribbed araphid diatoms from the genera Diatoma and Meridion (Diatomaceae: Bacillariophyta). Bibl. Diatomol. 8: 1-228.

Williams, D.M., 1990. Cladistic analysis of some freshwater araphid diatoms (Bacillariophyta) with particular reference to Diatoma and Meridion. Pl. Syst. Evol. 171: 89-97.

Williams, D.M. \& F.E. Round, 1988. Phylogenetic systematics of Synedra. In F.E. Round (ed.), Proceedings of the 9th International Diatom Symposium. O. Koeltz \& BioPress, Koenigstein and Bristol: 303-315. 